\title{
NATURAL COVER SURROUNDING THE FARM FIELD REDUCES CROP DAMAGE AND PEST ABUNDANCE IN BRAZILIAN DRYLAND ${ }^{1}$
}

\author{
HELDER FARIAS PEREIRA DE ARAUJO ${ }^{2}$, NAYSA FLÁVIA FERREIRA DO NASCIMENTO ${ }^{3}$, \\ CARLOS HENRIQUE DE BRITO²*
}

\begin{abstract}
One of the major ecosystem services delivered to agriculture worldwide is the reduction of pests by natural enemies. However, the landscape composition affects multiple dimensions of pest control, and non-crop habitat surrounding farm fields shows variable responses across geographies. Here, crop damage and pest abundance were compared between local farms with two antagonistic land cover and land use aspects (1High conservation, landscape with high structural complexity; 2- High degradation, landscapes with low complexity). The field data were collected at experimental guava orchards in the Cariri Paraibano, one of the driest regions in the Brazilian Caatinga. The results show that damage caused by orthopterans and their abundance was significantly smaller in the landscape with high structural complexity. Therefore, the results support the hypothesis that crop damage and pest abundance are smaller in landscapes with high structural complexity. Additionally, the results are very important for the dryland regions as they provide information about the relationship between landscape structure and crop damage plus pest abundance in a regional gap. As drylands are critically endangered in all American continents, sustainable agricultural landscapes with the application of natural cover restoration can help drylands to achieve sustainable development.
\end{abstract}

Keywords: Ecosystems services. Biological control. Landscape complexity. Semiarid. Sustainable development.

\section{A COBERTURA NATURAL AO REDOR DO CAMPO REDUZ OS DANOS ÀS LAVOURAS E A ABUNDÂNCIA DE PRAGAS NAS TERRAS SECAS DO BRASIL}

RESUMO - Um dos principais serviços ecossistêmicos prestados à agricultura em todo o mundo é a redução de pragas por inimigos naturais. No entanto, a composição da paisagem afeta várias dimensões do controle de pragas, e o habitat não agrícola ao redor dos campos agrícolas mostra respostas variáveis entre diferentes regiões do globo. Nesse trabalho, danos por herbivoria e abundância de pragas foram comparados entre duas paisagens com distintas cobertura e uso do solo (1 - conservada, com alta complexidade estrutural; e 2 degradada, com baixa complexidade). As observações de campo foram realizadas em plantios experimentais de goiabeiras, no Cariri Paraibano, uma das regiões mais secas da Caatinga. Os resultados obtidos demonstram que danos provocados por insetos da ordem Orthoptera, especialmente gafanhotos, bem como sua abundância, foram significativamente menores na paisagem com de alta complexidade estrutural. Portanto, esses resultados apoiam a hipótese que danos às culturas e a abundância de pragas são menores em paisagens com alta complexidade estrutural. Além disso, os resultados são muito importantes para as regiões semiáridas, pois fornecem informações sobre a relação entre a estrutura da paisagem e os danos à cultura em uma lacuna regional. Como as regiões semiáridas são ecossistemas criticamente ameaçados em todo o continente americano, paisagens agrícolas sustentáveis com ações de restauração florestal podem ajudar essas regiões a alcançar o desenvolvimento sustentável.

Palavras-chave: Serviços ecossistêmicos. Controle biológico. Complexidade de paisagem. Semiárido. Desenvolvimento sustentável.

\footnotetext{
${ }^{*}$ Corresponding author

${ }^{1}$ Received for publication in 09/01/2020; accepted in 08/18/2021

Project MCTIC/CNPq Nexus I

${ }^{2}$ Department of Biosciences, Universidade Federal da Paraíba, Areia, PB, Brazil; helder@cca.ufpb.br - ORCID: 0000-0001-6237-6490, carlos@cca.ufpb.br - ORCID: 0000-0002-0195-0986.

${ }^{3}$ Department of Phytotechny and Enviromental Sciences, Universidade Federal da Paraíba, Areia, PB, Brazil; naysa.flavia@academico.ufpb.br-ORCID: 0000-0002-4857-3874.
} 


\section{INTRODUCTION}

One of the major economic and environmental losses is the application of pesticides in croplands due to public health, pesticide resistance, crop losses, biodiversity losses because of pesticides, and groundwater contamination (OERKE, 2006; PIMENTEL, 2009). The use of biological control is a non-chemical and environmentally friendly method for the management of crop pests (SANDA; SUNUSI, 2014), with a highly favorable cost-benefit ratio and much lower development costs than chemical control (BALE; VANLENTEREN; BIGLER, 2008). Pest control by natural enemies is an essential ecosystem service valued at $\$ 4.49$ billion annually in the USA alone (LOSEY; VAUGHAN, 2006). In the context of increasing pressure to reduce harmful chemical inputs while maintaining or increasing current agricultural yields, the gradual replacement of conventional agricultural practices with natural pest control is a major hope for the future (BOMMARCO; KLEIJN; POTTS, 2013). However, biological control of crop pests is influenced by agricultural landscape complexity (JONSSON et al., 2015).

Some syntheses and instances have demonstrated that non-crop habitats surrounding farm fields provide requisites for natural enemies, and, therefore, agricultural landscape complexity affects natural pest control positively and decreases crop damage (BALZAN; BOCCI; MOONEN, 2016; BIANCHI; BOOIJ; TSCHARNTKE, 2006; RUSCH et al., 2016; THIES; STEFFAN-DEWENTER; TSCHARNTKE, 2003; VERES et al., 2013). Even with natural enemy augmentation as a biological control approach, pest predation rates and crop biomass increase, and plant damage and pest abundance decrease in complex landscapes, and the inverse occurs in simple landscapes (PEREZALVAREZ et al., 2019). However, a global analysis shows that landscape composition affects multiple dimensions of pest control, and non-crop habitat surrounding farm fields shows variable responses across geographies and cropping systems (KARP et al., 2018). Thus, these authors point out the need to understand when habitat conservation truly represents a win-win benefit and how landscape effects help local farms with biological control management.

Land use for unsustainable agriculture is the major driver of dryland degradation around the world, and it causes landscape simplification by reducing habitats (RAMANKUTTY et al., 2018; STEWART; KOOHAFKAN; RAMAMOORTHY, 2006; TAYLEUR et al., 2017; YIRDAW; TIGABU; MONGE, 2017). However, agriculture also has an essential role in economic development and poverty reduction in dryland regions (SARRIS, 2001; STEWART, 2016). Drylands are one of the most degraded ecosystems and, consequently, are among the most vulnerable areas in the world (ARAB WATER COUNCIL, 2009; FERRER-PARIS et al., 2019; REYNOLDS et al., 2007). Drylands cover $41.3 \%$ of the world's land and are home to 2.1 billion people (SÖRENSEN, 2007; WHITE; NACKONEY, 2003). About $50 \%$ of them depend on rural livelihoods, are among the most marginalized people, and live in the most vulnerable areas compared to other ecosystems (STAFFORD SMITH et al., 2009; UNDDD, 2010). In the Caatinga, one of the most populated tropical drylands of the world, intense degradation (including leading to desertification) was generated by land use for agriculture. From the late 19th century to the 1970s, cotton production created a vibrant economy in the region. Nevertheless, this activity declined sharply from the $1950 \mathrm{~s}$ due to the international market, land mismanagement, and pest (BELTRÃO, 2003; COSTA; BUENO, 2004). After that, most of the region has inadequate practices of livestock farming, agriculture, and wood extraction. With the continuity of these practices, several areas of the region have become susceptible to desertification contributing to the loss of biodiversity and ecosystems services, and soil degradation (SÁ et al., 2010; VIEIRA et al., 2015).

One of the solutions to protecting drylands while improving people's lives is to implement sustainable agricultural landscapes (ARAUJO et al., 2021; SAYER et al., 2013; SCHERR; MCNEELY, 2008; SILVA; BARBOSA, 2018). Landscape planning with ecosystem services is an approach to achieve sustainable agricultural landscapes (ALBERT; VON HAAREN; LOVETT, 2019; LANDIS, 2017), and how to decrease crop pests is an important ecosystem service to be evaluated (KARP et al., 2018). Therefore, this paper aimed to test if crop damage and pest abundance are influenced by landscape structure in the Caatinga. For that, field data from guava orchards were collected in two local farms with antagonistic land cover and land use aspects (1- High conservation, landscape with high structural complexity; 2- High degradation, landscape with low complexity).

\section{MATERIAL AND METHODS}

\section{Study area}

Field data were collected from two landscape units in the Brazilian semiarid region, known as Caatinga, the largest South American dryland (SILVA et al., 2017). Specifically, the field data are from Cariri Paraibano, a region where annual precipitation ranges from 350 to $800 \mathrm{~mm}$, and over $60 \%$ of this is concentrated in the months of February, March, and April (ALVARES et al., 2013) (Figure 1). The annual average temperature and humidity are $25{ }^{\circ} \mathrm{C}$ and $65 \%$, respectively. The Cariri 
Paraibano was covered by woodlands, riverine forests, and rocky outcrops until the 18th century, but most of the original vegetation was replaced with cotton fields from the late 19th century to the 1970s (SOUZA; SOUZA, 2016). Currently, the local people struggle to improve their social indicators while managing their low stocks of natural resources (ALVES; AZEVEDO; CÂNDIDO, 2017; PEREIRA -JÚNIOR et al., 2015). However, there are landscapes with distinct historical land use and land cover in the Cariri Paraibano, making it possible to test the influence of these landscapes on crop damage and pest abundance.

To collect data in landscapes with high and low structural complexity, experimental plantations were established on two farms with distinct land cover and land use. Although there are many definitions of complexity, more complex systems require more information to describe any given state of that system (NEWMAN et al., 2019). Then, the data from a landscape with high structural complexity are collected on the Fazenda Almas (ALMAS - 7²7'30.86"S , 36 $53^{\circ} 29.49^{\prime \prime} \mathrm{W}$ ), the most conservation area in the Cariri Paraibano localized in the municipality of São José dos Cordeiros. A private reserve has been established on this farm for over 40 years, where it maintains a major diversity of natural habitats (BARBOSA et al., 2007) (Figure 1). The data from the landscape with low structural complexity are from the municipality of São João do Cariri (ESJC - $\left.7^{\circ} 22^{\prime} 21.46^{\prime \prime} \mathrm{S}, 36^{\circ} 31^{\prime} 42.41^{\prime \prime} \mathrm{W}\right)$, which was historically occupied by cotton fields, extensive goat farming, and exploratory removal of native vegetation (BARBOSA et al., 2007) (Figure 1). Currently, this region is characterized as a desertification hotspot in Brazilian semiarid, named Cariris Velhos (PEREZ-MARIN et al., 2012; TRAVASSOS; SOUSA, 2014). Due to natural habitat reduction, this is the landscape with low structural complexity.

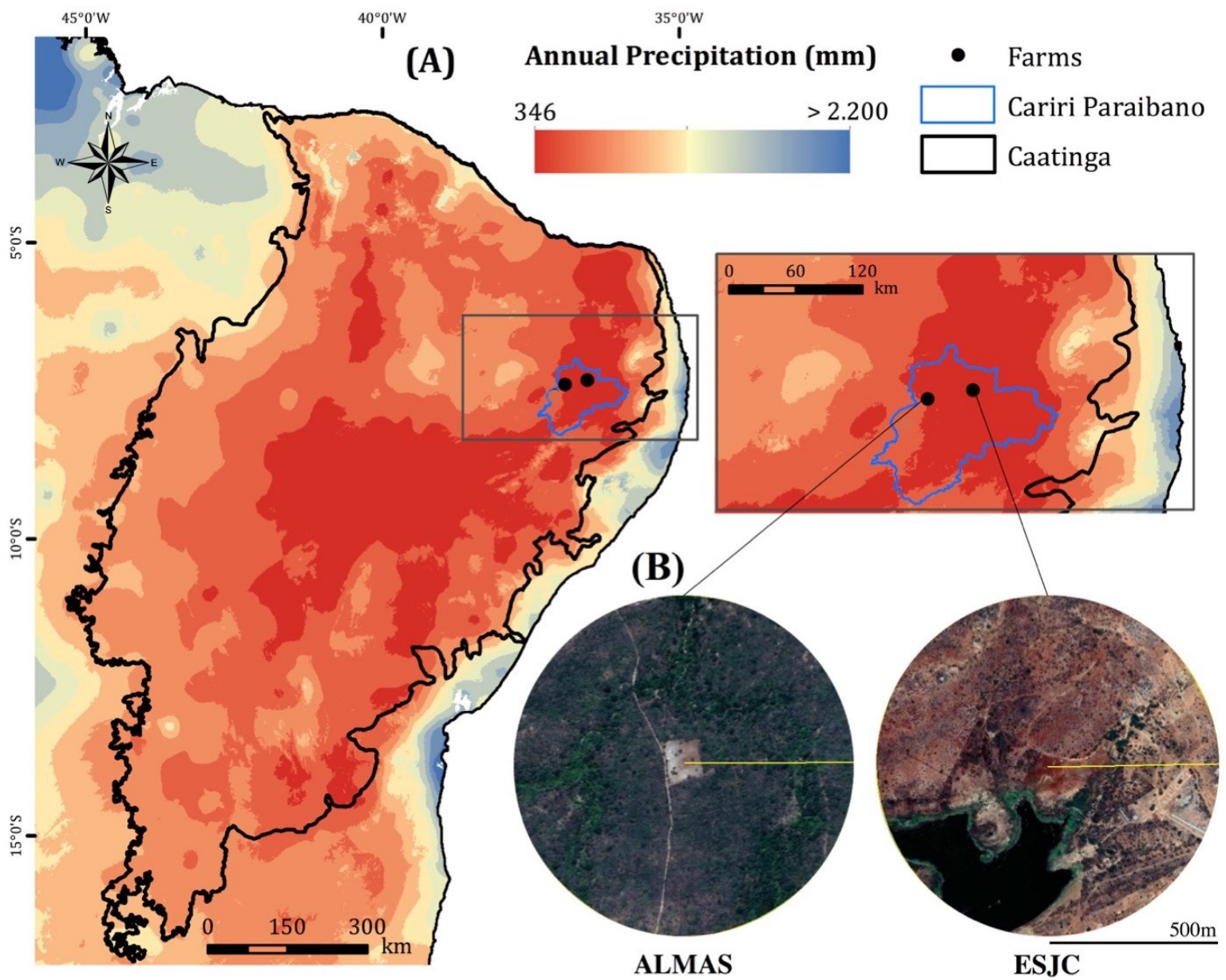

Figure 1. (A) The study area is located in Cariri Paraibano, a sub-region of Caatinga, Brazil, that has a very seasonal rainfall pattern. (B) ALMAS represents the best conservation area in the region, and ESJC represents the degraded landscape. The guava orchards are in the center of each buffer. 


\section{Data collection}

Crop damage and pest abundance were evaluated in an experimental planting of guavas (Psidium guajava L.) during the late rainy season, February 2020. Guava seedlings were planted in August 2019 at each farm, where phosphorus and manure were used as basal fertilizers. The cultivar Paluma was used because it is a common guava tree planted in the Brazilian semiarid region, due to its high productivity and versatility for fresh and industrial consumption (ALENCAR et al., 2016). The experimental guava orchards were daily irrigated, and guava trees were about $1 \mathrm{~m}$ in height during the current evaluation.

Crop damage by herbivores and pest abundance were estimated from 30 plants separated by $6 \mathrm{~m}$ between rows and $5 \mathrm{~m}$ between plants at each farm. The indicators of crop damage were the damaged leaves proportion and damage intensity caused by herbivory. Both were estimated by direct counting on branches with more than 50 leaves per tree. Damaged leaves proportion (\%) is the ratio between the number of leaves with any injury and the total of leaves counted. Damage intensity (\%) is the average injury per plant indicated by rank estimation of leaf cover with damage by herbivory (from 10 to $100 \%$ ). Herbivore pest abundance was estimated by direct counting the number of pests in each tree. The insects were classified up to the Family taxonomy category based on Borror and Delong (2004).

\section{Statistics}

Damaged leaves proportion, damage intensity, and pest abundance were compared between each farm using Kernel Density Estimation (KDE) and Mann-Whitney U test. Both statistical approaches are used to represent non-parametric data, and KDE is used for inferences about data smoothing problems based on a finite data sample (CHAUDHURI; MARRON, 2000; CORDER; FOREMAN, 2014). 'sm' package and 'wilcox.test' function were used in the $\mathrm{R}$ program to perform these statistical approaches (BOWMAN; AZZALINI, 2019).

\section{RESULTS AND DISCUSSION}

Damaged leaves proportion varied significantly $(\mathrm{z}=-6.13, \mathrm{p}<0.0001)$ with about $10 \%$ and $85 \%$ of damaged leaves in landscapes with high and low structural complexity, respectively (Figures 2, 3). Damage intensity follows the same pattern $(\mathrm{z}=-5.63, \mathrm{p}<0.0001)$, with the greater values found on the farm with low structural complexity (Figures $2,3)$. The herbivores recorded were orthopterans, and stick grasshoppers (Proscopiidae) were the most common in both farms (Figure 4). Pest abundance was significantly lower on the farm with high structural complexity $(\mathrm{z}=-6.47, \mathrm{p}<0.0001)$ (Figures 2, 3).

The results support that crop damage and pest abundance are significantly smaller in landscapes with high structural complexity when compared to simple landscapes (BALZAN; BOCCI; MOONEN, 2016; BIANCHI; BOOIJ; TSCHARNTKE, 2006; THIES; STEFFAN-DEWENTER; TSCHARNTKE, 2003). This effect can be caused by increasing shelters for the natural enemy, by increasing semiochemicals which act to repel pests and attract natural enemies, and, consequently, by increasing local natural enemy diversity in complex landscapes (CHAPLIN-KRAMER et al., 2011; GURR et al., 2017; KHAN et al., 2008). The frequency of the natural enemies depends on permanent habitats for nestling and available resources (BIANCHI; BOOIJ; TSCHARNTKE, 2006), and these habitats allow the displacement of organisms between them and farm fields (TSCHARNTKE; RAND; BIANCHI, 2005). Therefore, the results found here are very important for the dryland region in Brazil as they provide information about the relationship between landscape structure and crop damage plus pest abundance in a regional gap (KARP et al., 2018). As drylands are critically endangered in all American continents (FERRER-PARIS et al., 2019), sustainable agricultural landscapes with the application of natural cover restoration can help drylands to achieve resilience and sustainable development (LANDIS, 2017).

One of the major ecosystem services delivered to agriculture worldwide is the reduction of pests by natural enemies (MARTIN et al., 2013). During the 1980s in the Caatinga, the main agricultural economy declined, and the cotton pest (Anthonomus grandis Boheman 1843 - Coleoptera: Curculionidae) was an emblematic cause (BELTRÃO, 2003; COSTA; BUENO, 2004). However, the agricultural landscapes for cotton production have been replaced due to a change from perennial tree cotton to herbaceous cotton production. This replacement caused a significant landscape simplification with an expansion of the monoculture area and promoted one of the major reductions of natural cover in the region. Landscape simplification was the most pervasive problem for sustainable agriculture in drylands worldwide due to the loss of essential ecosystem services (YIRDAW; TIGABU; MONGE, 2017), and biological control by natural enemies can be cited as one instance. 
A
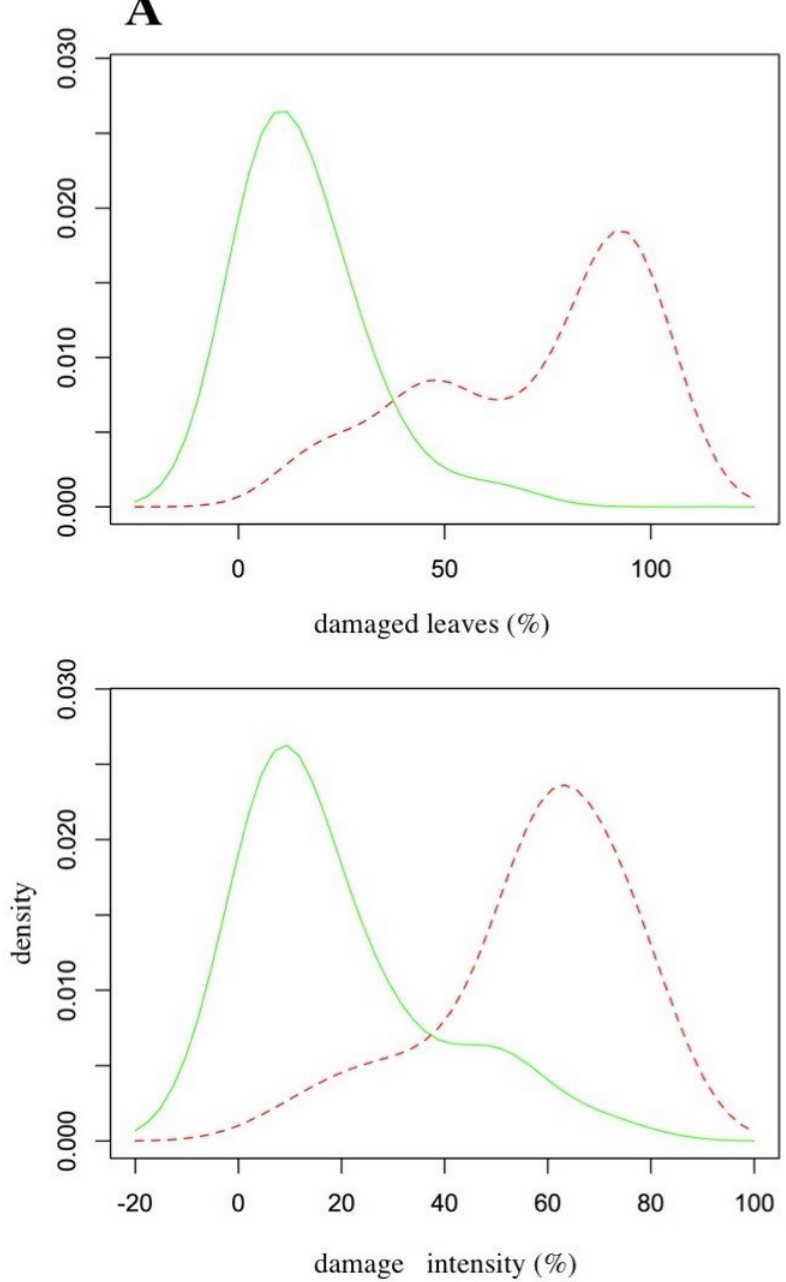

damage intensity $(\%)$

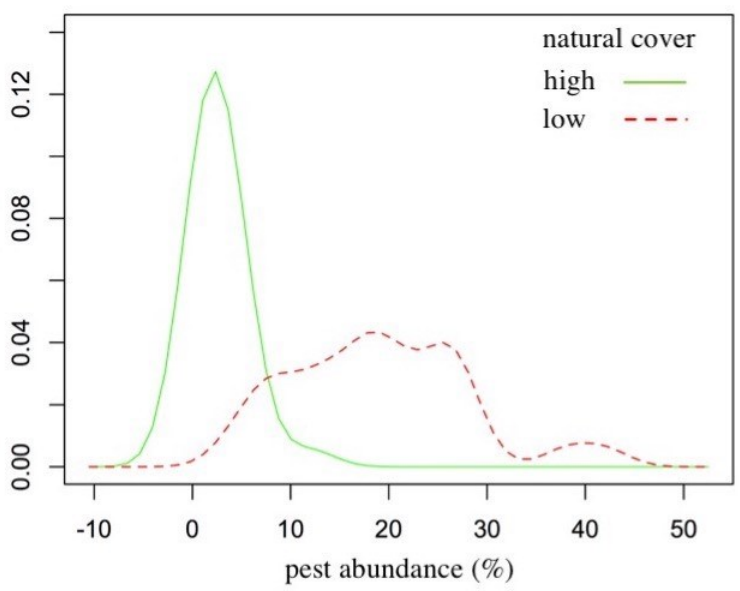

B
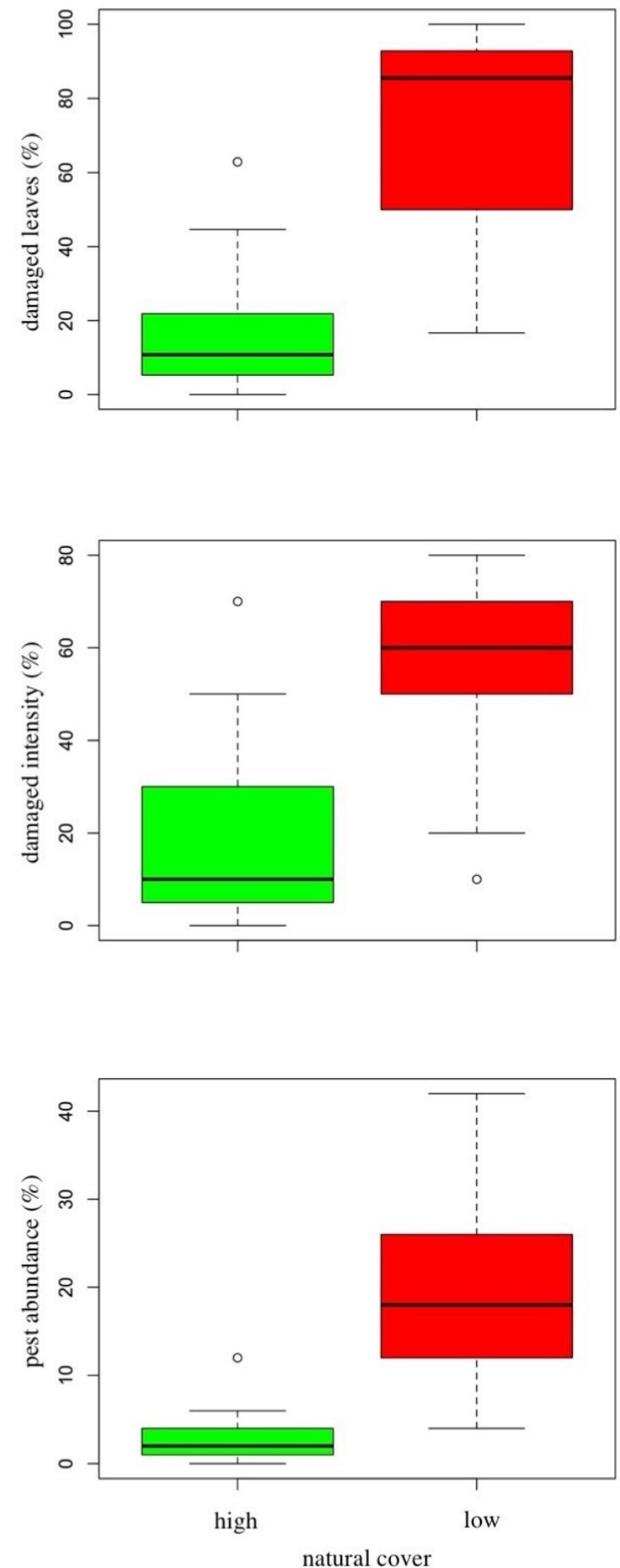

Figure 2. Kernel Density Estimation (A) and Box-plot (B) show the comparison of damaged leaves proportion, damage intensity, and pest abundance between the farms with high structural complexity (green) and low structural complexity (red). 

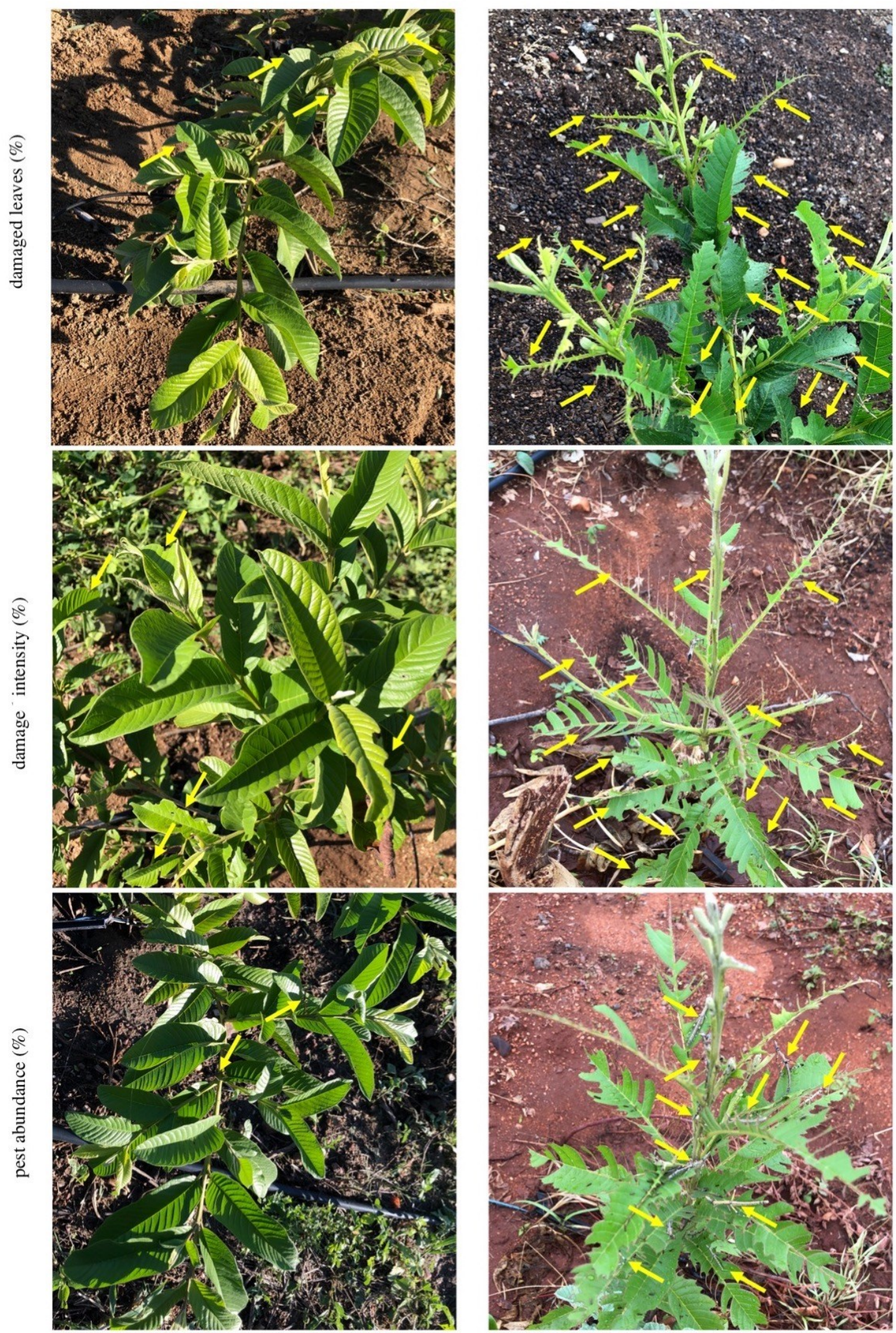

high
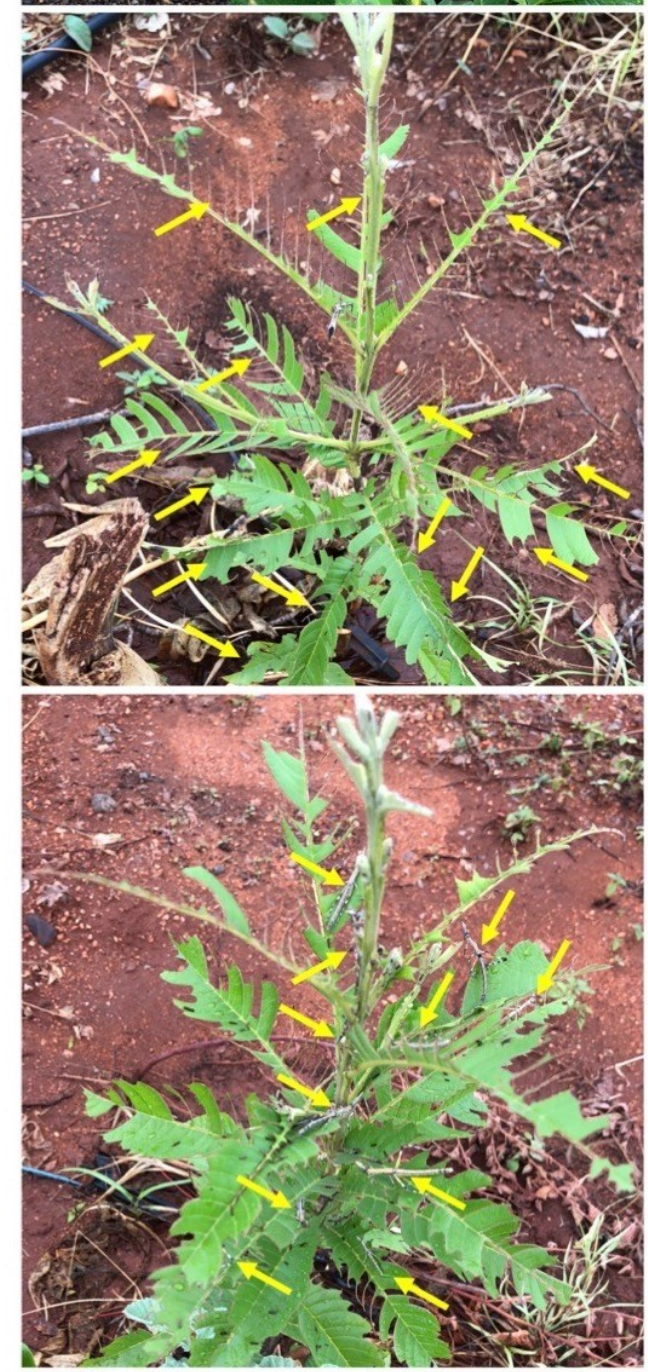

low

natural cover

Figure 3. Damaged leaves proportion, damage intensity, and pest abundance in guava trees at the farms with high structural complexity (high natural cover) and low structural complexity. 
A
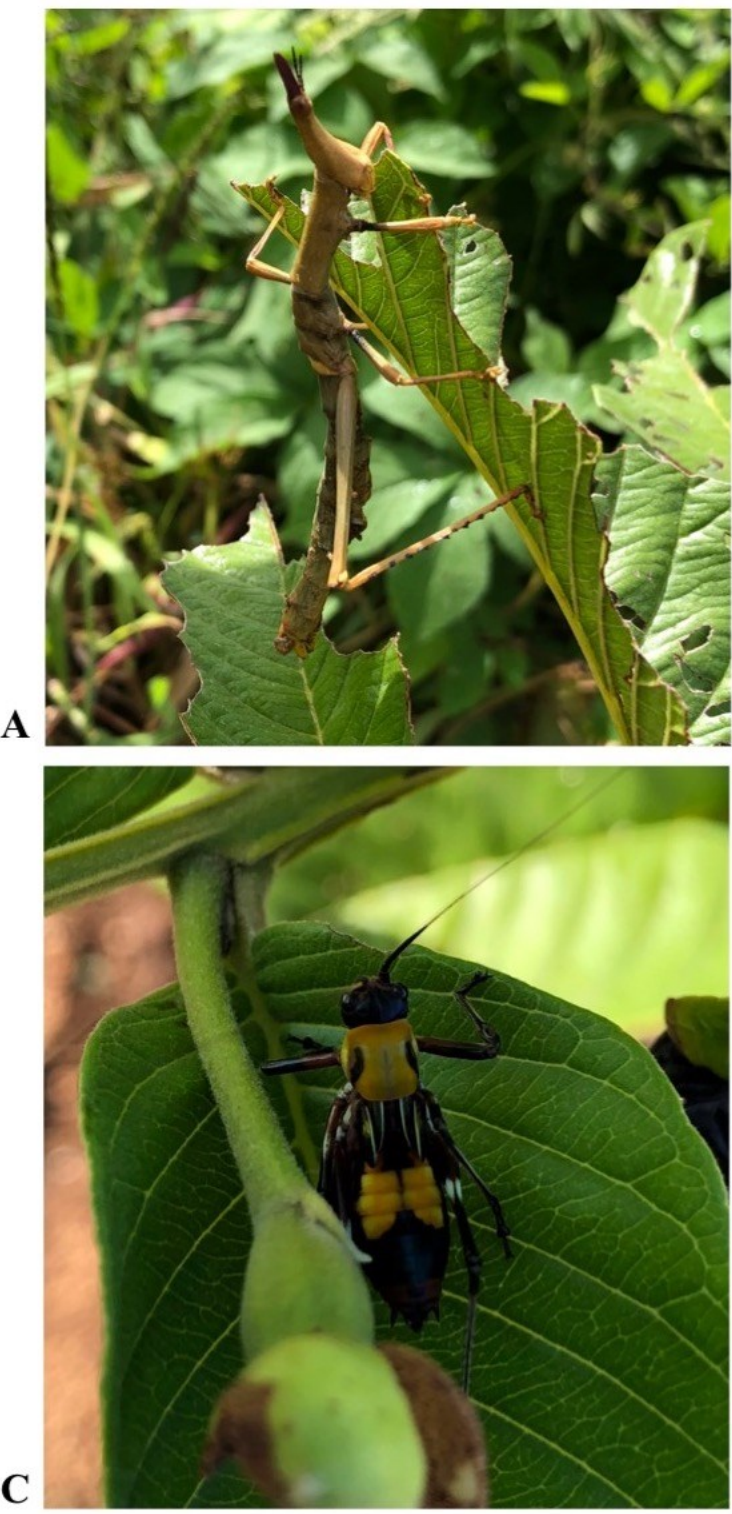

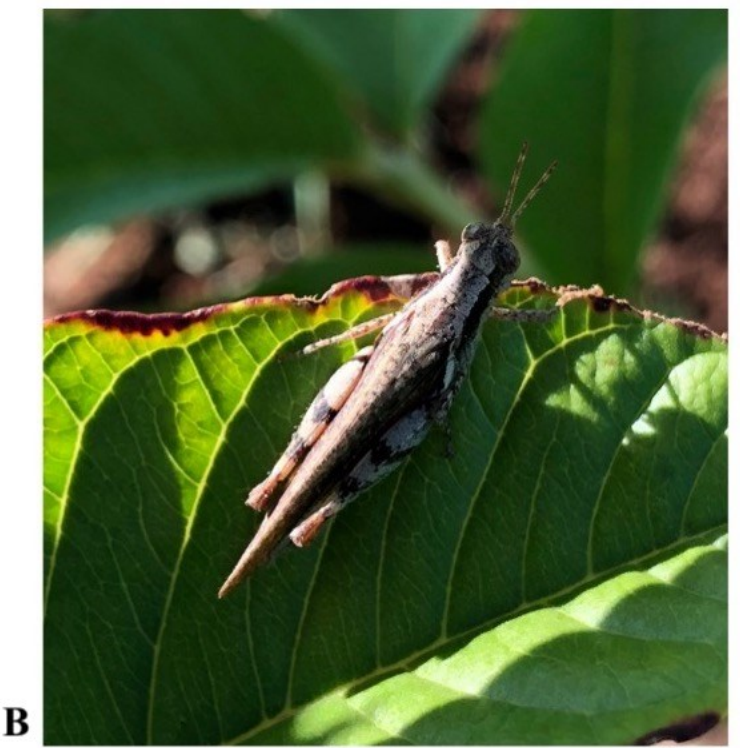

D

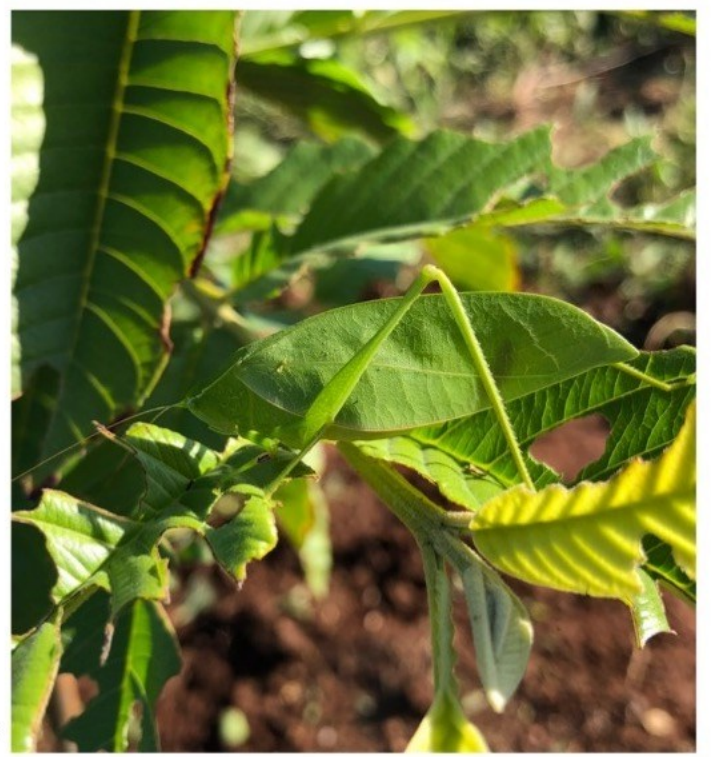

Figure 4. Herbivore orthopteran insects recorded in guava orchards at the farms with high structural complexity and low structural complexity. A - Proscopiidae, B - Acrididae, C - Nymph of Acrididae, D - Tettigoniidae.

Negative interactions between birds and flying insect enemies can constrain pest control in some complex agricultural landscapes (MARTIN et al., 2013). Nevertheless, the results found here show that natural cover is essential to pest control in the dryland region when landscape complexity is intensified. Grasshoppers were the main pest in the case study, and native birds are grasshopper predators in the Caatinga (ARAUJO, 2009). However, insectivore bird diversity is reduced and replaced with granivorous bird diversity when the natural cover decreases (ARAUJO; SILVA, 2017; ARRUDA, 2017). Besides reducing crop damage because of pest control, the natural cover provides other essential agricultural services such as increasing pollinator habitats, reducing erosion rates, and increasing soil water infiltration (LEITE et al., 2018; WRATTEN et al., 2012). Therefore, habitat management is urgent to ensure sustainable agricultural landscapes in drylands (GURR et al., 2017).

Finally, sustainable agricultural systems are needed to feed a growing human population, and landscape planning with ecosystem services is crucial for achieving this target (LANDIS, 2017; VON HAAREN; LOVETT; ALBERT, 2019). As is true for other drylands in the world, the Brazilian semiarid region is vulnerable because of inadequate historical land use for agricultural practice (ARAB WATER COUNCIL, 2009; FERRER-PARIS et al., 2019; REYNOLDS et al., 2007). Therefore, active actions to change this scenario must apply more 
conservation of these ecosystems, including natural restoration, to achieve sustainable agricultural landscapes (ARAUJO et al. 2021). The information from the present study shows how crop damage and pest abundance are reduced in a landscape with more natural cover when compared with another landscape with low structural complexity. These results show a significant difference and agree with the same pattern around the world (BALZAN; BOCCI; MOONEN, 2016; BIANCHI; BOOIJ; TSCHARNTKE, 2006; THIES; STEFFANDEWENTER; TSCHARNTKE, 2003). Besides that, other economic and environmental agricultural losses can be decreased by adopting natural cover surrounding the farm fields, as well as reducing pesticide use and the negative effects of pesticides on pollinators (PARK et al., 2015).

\section{CONCLUSION}

Crop damage by herbivores, especially grasshoppers, and pest abundance in guava orchards are significantly smaller in farm fields surrounded by natural cover when compared to the fields in landscapes with low natural cover. This shows the importance of combining natural and crop cover to benefit agricultural development in the Caatinga, which is the most vulnerable region in South America due to land degradation.

\section{ACKNOWLEDGMENTS}

This work was supported by the Brazilian National Council for Scientific and Technological Development (CNPq) [grant number 441436/20170]. We thank Mr. José de Arimatéa Braz for his collaboration and permission to access work lands at the Almas farm.

\section{REFERENCES}

ALBERT, C.; VON HAAREN, C.; LOVETT, A. A. Synthesis and Prospects for Landscape Planning. In: C. von Haaren, A. A. Lovett, C. Albert (Eds.). Landscape Planning with Ecosystem Services: Theories and Methods for Application in Europe, The Netherlands: Springer Nature, 2019. Part VI, p. 495-499.

ALENCAR, R. D. et al. Adubação potássica na produção e qualidade pós-colheita de goiaba 'Paluma'no semiárido potiguar. Comunicata Scientiae, 7: 139-148, 2016.
ALVARES, C. A. et al. Köppen's climate classification map for Brazil. Meteorologische Zeitschrift, 22: 711-728, 2013.

ALVES, T. L. B.; AZEVEDO, P. V.; CÂNDIDO, G. A. Socioeconomic indicators and desertification in the upper course of the Paraíba river watershed. Ambiente \& Sociedade, 20: 19-38, 2017.

ARAB WATER COUNCIL. Vulnerability of arid and semi-arid regions to climate change Impacts and adaptive strategies. 2009. Disponível em: $\quad<$ https://www.preventionweb.net/go/12914>. Acesso em: 25 Ago. 2020.

ARAUJO, H. F. P.et al. A sustainable agricultural landscape model for tropical drylands. Land Use Policy, 100: 104913, 2021.

ARAUJO, H. F. P. Amostragem, Estimativa de Riqueza de Espécies e Variação Temporal na Diversidade, Dieta e Reprodução de Aves em Área de Caatinga, Brasil. 2009. 198 f. Tese (Doutorado em Ciências Biológicas: Área de Concentração em Zoologia) - Universidade Federal da Paraíba, João Pessoa, 2009.

ARAUJO, H. F. P.; SILVA, J. M. C. The Avifauna of the Caatinga: Biogeography, Ecology, and Conservation. In: Caatinga. Springer International Publishing, 2017. p. 181-210.

ARRUDA, A. R.. Efeito de variáveis ambientais e alteração da vegetação na riqueza de endemismos e comunidades de aves na Caatinga. Tese de doutorado - Universidade Federal da Paraíba, 2017.

BALE, J.; VAN LENTEREN, J.; BIGLER, F. Biological control and sustainable food production. Philosophical Transactions of the Royal Society B: Biological Sciences, 363: 761-776, 2008.

BALZAN, M. V.; BOCCI, G.; MOONEN, A.-C. Landscape complexity and field margin vegetation diversity enhance natural enemies and reduce herbivory by Lepidoptera pests on tomato crop. BioControl, 61: 141-154, 2016.

BARBOSA, M. R. V.et al. Vegetação do Cariri Paraibano. Oecologia Brasiliensis, 11: 313-322, 2007.

BELTRÃO, N. E. M. Breve História do Algodão no Nordeste do Brasil. Campina Grande, PB: Embrapa Algodão, 2003. 17 p.

BIANCHI, F. J. J.; BOOIJ, C. J; TSCHARNTKE, T. Sustainable pest regulation in agricultural 
landscapes: a review on landscape composition, biodiversity and natural pest control. Proceedings of the Royal Society B: Biological Sciences, 273: 1715-1727, 2006.

BOMMARCO, R.; KLEIJN, D.; POTTS, S. G. Ecological intensification: harnessing ecosystem services for food security. Trends in Ecology \& Evolution, 28: 230-238, 2013.

BORROR, D. J.; DELONG, C. T. Introduction to the Study of Insects (7th ed.). Cengage Learning, 2004. 888 p.

BOWMAN, A.; AZZALINI, A. Smoothing Methods for Nonparametric Regression and Density Estimation (Package 'sm'), 2019. 55 p

CHAPLIN-KRAMER, R. et al. A meta-analysis of crop pest and natural enemy response to landscape complexity. Ecology Letters, 14: 922-932, 2011.

CHAUDHURI, P.; MARRON, J. S. Scale space view of curve estimation. The Annals of Statistics, 28: 408-428, 2000

CORDER, G. W.; FOREMAN, D. I. Nonparametric Statistics: A Step-by-Step Approach. 2 ed. Wiley, 2014. 288 p.

COSTA, S. R.; BUENO, M. G. A saga do algodão: das primeiras lavouras à ação na OMC. Rio de Janeiro, RJ: Insight Engenharia, 2004. 144 p.

FERRER-PARIS, J. R. et al. An ecosystem risk assessment of temperate and tropical forests of the Americas with an outlook on future conservation strategies. Conservation Letters, 12: e12623, 2019.

GURR, G. M. et al. Habitat Management to Suppress Pest Populations: Progress and Prospects. Annual Review of Entomology, 62: 91-109, 2017.

JONSSON, M. et al. Experimental evidence that the effectiveness of conservation biological control depends on landscape complexity. Journal of Applied Ecology, 52: 1274-1282, 2015.

KARP, D. S. et al. Crop pests and predators exhibit inconsistent responses to surrounding landscape composition. Proceedings of the National Academy of Sciences, 115: 7863-7870, 2018.

KHAN, Z. R. et al. Chemical ecology and conservation biological control. Biological Control, 45: 210-224, 2008.

LANDIS, D. A. Designing agricultural landscapes for biodiversity-based ecosystem services. Basic and
Applied Ecology, 18: 1-12, 2017.

LEITE, P. A. M. et al. The influence of forest regrowth on soil hydraulic properties and erosion in a semiarid region of Brazil. Ecohydrology, 11: e1910, 2018.

LOSEY, J. E.; VAUGHAN, M. The economic value of ecological services provided by insects. BioScience, 56: 311-323, 2006.

MARTIN, E. A. et al. Natural enemy interactions constrain pest control in complex agricultural landscapes. Proceedings of the National Academy of Sciences, 110: 5534-5539, 2013.

NEWMAN, E. A. et al. Scaling and Complexity in Landscape Ecology. Frontiers in Ecology and Evolution, 7, 2019.

OERKE, E. C. Crop losses to pests. The Journal of Agricultural Science, 144: 31-43, 2006.

PARK, M. G.et al. Negative effects of pesticides on wild bee communities can be buffered by landscape context. Proceedings of the Royal Society B: Biological Sciences, 282: 1-9, 2015.

PEREIRA-JÚNIOR, L. R. et al. Socioeconomic and diagnostic strategies for living with drought in semiarid region. Engenharia Ambiental, 12: 168$184,2015$.

PEREZ-ALVAREZ, R. et al. Effectiveness of augmentative biological control depends on landscape context. Scientific Reports, 9:1-15, 2019.

PEREZ-MARIN, A. et al. Núcleos de desertificação no semiárido brasileiro: Ocorrência natural ou antrópica? Parcerias Estratégicas, 17: 106, 2012.

PIMENTEL, D. Environmental and Economic Costs of the Application of Pesticides Primarily in the United States. In: R. PESHIN; A. K. DHAWAN (Eds.), Integrated Pest Management: InnovationDevelopment Process. Dordrecht: Springer Netherlands, 2009. v. 1, p. 89-111.

RAMANKUTTY, N. et al. Trends in Global Agricultural Land Use: Implications for Environmental Health and Food Security. Annual Review of Plant Biology, 69: 789-815, 2018.

REYNOLDS, J. F.et al. Global Desertification: Building a Science for Dryland Development. Science, 316: 847-851, 2007.

RUSCH, A. et al. Agricultural landscape simplification reduces natural pest control: A 
quantitative synthesis. Agriculture, Ecosystems \& Environment, 221: 198-204, 2016.

SÁ, I. B. et al. Processos de desertificação no Semiárido brasileiro. In I. . Sá \& P. C. G. Silva (Eds.), Semiárido brasileiro: pesquisa desenvolvimento e inovação Petrolina: Embrapa Semiárido, 2010. p. 125-158.

SANDA, N. B.; SUNUSI, M. Fundamentals of Biological Control of pests. IJCBS Review Paper, 1: 1-11, 2014.

SARRIS, A. The Role of Agriculture in Economic Development and Poverty Reduction. Rural Development Department - The World Bank, 2001. $86 \mathrm{p}$.

SAYER, J. et al. Ten principles for a landscape approach to reconciling agriculture, conservation, and other competing land uses. Proceedings of the National Academy of Sciences, 110: 8349-8356, 2013.

SCHERR, S. J.; MCNEELY, J. A. Biodiversity conservation and agricultural sustainability: towards a new paradigm of 'ecoagriculture' landscapes. Philosophical Transactions of the Royal Society B: Biological Sciences, 363: 477-494, 2008.

SILVA, J. M. C.; BARBOSA, L. C. F. Sustainable Agriculture Landscapes for Production of Biofuels in Brazil. In: BAGLEY, S. B. et al. (Eds.), Energy Security, sustainable Development, and the Environment. Lanham, Boulder, New York, London: Lexington Books, 2018. p. 95-109.

SILVA, J. M. C. et al. The Caatinga: Understanding the Challenges. In: Caatinga. Springer International Publishing, 2017. p. 3-19.

SÖRENSEN, L. A spatial analysis approach to the global delineation of dryland areas of relevance to the CBD Programme of Work on Dry and Subhumid Lands, 2007. Available at: Cambridge. $<$ https://www.unepwcmc.org/system/ dataset_file_fields/files/000/000/323/original/ dryland report final HR.pdf?1439378321>. Access on: Aug. 25, 2020.

SOUZA, B. I.; SOUZA, R. S. The occupation process of the Cariri Velhos - PB and the effects in the vegetal cover: contribution to the Cultural Biogeography of the semiarid. Caderno de Geografia, 26: 229-258, 2016.

STAFFORD SMITH, D. M. et al. Drylands: Coping with Uncertainty, Thresholds, and Changes in State. In: Principles of Ecosystem Stewardship. Springer
New York, 2009. p. 171-195.

STEWART, B. A. Dryland Farming. In Reference Module in Food Science. Amsterdam, The Netherlands: Elsevier, 2016. 10 p.

STEWART, B. A.; KOOHAFKAN, P.; RAMAMOORTHY, K. Dryland Agriculture Defined and Its Importance to the World. In: PETERSON, G. A.; UNGER, P. W.; PAYNE, W. A. (Eds.). Dryland Agriculture. Madison, USA: American Society of Agronomy, 2006. p. 1-26.

TAYLEUR, C. et al. Global Coverage of Agricultural Sustainability Standards, and Their Role in Conserving Biodiversity. Conservation Letters, 10: 610-618, 2017.

THIES, C.; STEFFAN-DEWENTER, I.; TSCHARNTKE, T. Effects of landscape context on herbivory and parasitism at different spatial scales. Oikos, 101: 18-25, 2003.

TRAVASSOS, I. S.; SOUSA, B. I. Desmatamento e Desertificação no Cariri Paraibano. Brasileira de Geografia Fisica, 7: 103-116, 2014.

TSCHARNTKE, T.; RAND, T. A.; BIANCHI, F. J. J. A. The landscape context of trophic interactions : insect spillover across the crop-noncrop interface. Annales Zoologici Fennici, 42: 421-432, 2005.

UNDDD - United Nations. United Nation decade for deserts and fight against desertification. Disponível em: <http://www.un.org/en/events/ desertification decade/whynow.shtml $>$. Acesso em: 25 ago. 2020

VERES, A. et al. Does landscape composition affect pest abundance and their control by natural enemies? A review. Agriculture, Ecosystems \& Environment, 166: 110-117, 2013.

VIEIRA, R. M. S. P. et al. Identifying areas susceptible to desertification in the Brazilian northeast. Solid Earth, 6: 347-360, 2015.

VON HAAREN, C.; LOVETT, A. A.; ALBERT, C. Landscape Planning and Ecosystem Services: The Sum is More than the Parts. In: VON HAAREN, C. et al. (Eds.). Landscape Planning with Ecosystem Services: Theories and Methods for Application in Europe. The Netherlands: Springer Nature, 2019. Part I, p. 3-9.

WHITE, R. P.; NACKONEY, J. Drylands, people, and ecosystem goods and services: $A$ webbased geospatial analysis. 2003. Disponível em: <http:// 
pdf.wri.org/drylands.pdf>. Acesso em: 25 ago. 2020.

WRATTEN, S. D. et al. Pollinator habitat enhancement: Benefits to other ecosystem services. Agriculture, Ecosystems \& Environment, 159: 112-122, 2012.

YIRDAW, E.; TIGABU, M.; MONGE, A. Rehabilitation of degraded dryland ecosystems review. Silva Fennica, 51: 1-32, 2017. 